\title{
Resistance to Apramycin in Escherichia coli Isolated from Animals: Detection of a Novel Aminoglycoside-modifying Enzyme
}

\author{
By R. W. HEDGES ${ }^{1}+$ AND K. P. SHANNON ${ }^{2 *}$ \\ ${ }^{1}$ Department of Bacteriology, Royal Postgraduate Medical School, Hammersmith Hospital, \\ London WI2 OHS, UK \\ ${ }^{2}$ Department of Microbiology, St Thomas's Hospital Medical School, London SEI 7EH, UK
}

(Received 19 August 1983; revised 21 October 1983)

\begin{abstract}
The mechanisms of resistance to apramycin of five isolates of Escherichia coli from animals were investigated. Three isolates, which were resistant to all the aminoglycosides tested, did not transfer their resistance and did not produce aminoglycoside-modifying enzymes. The fourth isolate, which was resistant to apramycin, tobramycin, gentamicin, kanamycin and neomycin but not to amikacin, owed its resistance to production of the acetyltransferase AAC(3)IV. The gene specifying this enzyme was carried on a transposon, Tn800, on a plasmid designated $\mathrm{R} 1535$. The fifth isolate was resistant to apramycin, neomycin and kanamycin but not to gentamicin, tobramycin or amikacin. It produced an acetyltransferase that readily acetylated only apramycin, neomycin and paromomycin, a compound that is closely related to neomycin. Synthesis of this enzyme was specified by a chromosomal gene located near pyrD at about $20 \mathrm{~min}$ on the map of the E. coli $\mathrm{K} 12$ chromosome.
\end{abstract}

\section{INTRODUCTION}

The aminoglycoside apramycin is used extensively in veterinary medicine but not in the treatment of humans (Ose et al., 1967; Bowen et al., 1976; Walton, 1978). Resistance to this compound is rare in unselected enterobacteria (Ryden \& Moore, 1977) and the frequency of mutations to high-level resistance is extremely low (Bowen et al., 1967; Davies \& O'Connor, 1978), but resistant strains are detectable in nature especially after treatment of farm animals with apramycin (Bowen et al., 1976). In some cases conjugative transfer of resistance to apramycin has been demonstrated, implying that this property is plasmid-determined (Bowen $e t$ al., 1967; Davies \& O'Connor, 1978). In these cases the resistance was mediated by aminoglycoside 3- $N$-acetyltransferase IV [AAC(3)IV], an enzyme with a notably broad range of substrates and the only enzyme reported to modify apramycin (Davies \& O'Connor, 1978).

There are two mechanisms of resistance to aminoglycosides that do not involve production of aminoglycoside-modifying enzymes. Firstly, there is ribosomal resistance. Mutations at the rps $L$ locus can confer high levels of resistance to streptomycin but do not affect sensitivity to other aminoglycosides; however, low levels of resistance to these compounds is conferred by mutations at the nek and $r p l F$ loci (Brown \& Apirion, 1974; Hull, et al., 1976; Hancock, 1981). These mutations, in which a ribosomal protein component is altered, occur with a very low frequency $\left(<10^{-10}\right)$ in Escherichia coli K12. Secondly, mutations at a number of loci affecting energy metabolism, including hem $A, u b i D, u n c A, B$ and $e c f B$, confer low-level resistance to aminoglycosides by decreasing uptake of the compounds (for review see Hancock, 1981).

As no studies on apramycin resistance have been reported since the work of Davies \& $\mathrm{O}^{\circ}$ Connor (1978), we decided to investigate a small collection of apramycin-resistant isolates of

Abbretiation: AAC, aminoglycoside acetyltransferase (position of modification and different enzymes distinguished by suffixes).

† Present address: Plant Genetic Systems, Rijksuniversiteit Gent, Plateaustraat, B-9000 Gent, Belgium. 
Table 1. Derivatives of E. coli K12 used in the study

Strain no.

N728

HfrH

HfrB9

HfrKL99

HfrKL208

HfrKL96

JF568

JF568-2

KL188

KL188-4

AM 1248

$\mathrm{X} 195$

X195-2

$\mathrm{J} 53$

$\mathrm{J} 62$

J62-1

J62-2

W677
Characters

\author{
Hfr nek-728 metBl purfl lac \\ Hfr prototrophic \\ Hfr metBl \\ Hfr thi-1 lac \\ Hfr prototrophic \\ Hfr thi-l \\ F- proC24 aroA357 his-53 purE4I met-65 lacY29 rpsL97 \\ Rif ${ }^{\mathrm{R}}$ mutant of JF568 \\ $F^{-}$pyrD34 trp-45 his-68 thyA25 thi-1 rpsL118 \\ ompA mutant of KL188 \\ $F^{-}$leu thi his trp pdxA car recB21 recC22 sbcB15 hsdR rpsL \\ $\mathrm{F}^{-}$pro his trp met purB pyrF tyr lac rpsL \\ $\mathrm{Rif}^{\mathrm{R}}$ mutant of X195 \\ $\mathrm{F}^{-}$pro met \\ $F^{-}$pro his trp lac \\ $\mathrm{Nal}^{\mathrm{R}}$ mutant of $\mathrm{J62}$ \\ Rif ${ }^{\mathrm{R}}$ mutant of $\mathrm{J62}$ \\ $\mathrm{F}^{-}$thr leu thi lac mal gal xyl ara mtl tonA
}

Reference or source

Brown \& Apirion (1974)

J. T. Smith

Broda (1967)

Low (1973)

Low (1973)

Low (1973)

Foulds \& Chai (1978)

B. Bachmann

W. P. M. Hoekstra

Pearce \& Meynell (1968)

Coetzee et al. (1972)

Coetzee et al. (1972)

Benveniste \& Davies (1971)

$E$. coli to determine the mechanisms of resistance to this antibiotic in naturally occurring populations of this species.

\section{METHODS}

Bacterial strains and plasmids. A collection of five apramycin-resistant isolates of $E$. coli from animals (generously made available by R. Ryden of the Lilly Research Centre, Windlesham, Surrey, UK) was studied. Derivatives of $E$. coli $\mathrm{K} 12$ and plasmids used are listed in Tables 1 and 2. Sets of plasmids representative of all incompatibility groups (Hedges \& Jacoby, 1980) were also used. Escherichia coli TH20914, a clinical isolate from St Thomas' Hospital, was used as a producer of AAC(3)II and E. coli TH42662 was chosen as a representative strain that was resistant to gentamicin and other aminoglycosides without producing gentamicin-modifying enzymes. We also used Providencia stuartii 133 as a source of $\mathrm{AAC}\left(2^{\prime}\right)$ : this enzyme has not yet been found to be plasmiddetermined.

Genetic studies. Except where otherwise stated, the technique of Datta et al. (1971) and Coetzee et al. (1972) was used for plasmid transfer by conjugation. In cases where rates of transfer were expected to be low, a few drops of overnight cultures of donor and recipient were poured on a $45 \mathrm{~mm}$ diameter filter paper on the surface of a nutrient agar plate. After incubation overnight at $37^{\circ} \mathrm{C}$ the filters were washed with saline and the bacterial suspensions plated directly on selective medium. $\mathrm{Hfr}$ (or $\mathrm{F}^{\prime}$ ) crosses with $\mathrm{F}^{-}$recipients were performed as described by Clowes \& Hayes (1968). Molecular weights of plasmids were determined by agarose gel electrophoresis as described by Datta et al. (1979). The technique described by Coetzee et al. (1972) was used for determination of incompatibility groups. Transduction by phage PI was performed as described by Roth (1970). The technique of Bergmans et al. (1981) was used for transformation.

Selection of an ompA mutant. Phage K3hl was used to select an ompA mutant of strain KL188 and to distinguish between ompA and ompA $A^{+}$recombinants as described by Henning et al. (1978).

Susceptibility testing. Minimum inhibitory concentrations (MICs) of aminoglycosides were determined by agar dilution in Oxoid Diagnostic Sensitivity Test Agar (CM 261) with an inoculum of about $10^{3}$ to $10^{4}$ organisms per spot. The MIC was taken as the lowest concentration that completely suppressed growth after incubation at $37^{\circ} \mathrm{C}$ overnight. The aminoglycosides tested were apramycin, tobramycin, gentamicin, kanamycin, amikacin and neomycin. Susceptibilities to streptomycin and to antibiotics other than aminoglycosides were assessed by disc diffusion.

Aminoglycoside-modifying enzymes. The cellulose phosphate paper binding method was used (Ozanne et al., 1969). Cell extracts were prepared by suspending the cells from $10 \mathrm{ml}$ nutrient broth cultures in $1 \mathrm{ml}$ of supplemented Tris/maleate buffer, pH 7.8 (Haas \& Dowding, 1975) and subjecting them to ultrasonic disintegration. For acetylation the reaction mixture consisted of $10 \mu \mathrm{l}$ aminoglycoside solution $\left(20 \mu \mathrm{g} \mathrm{m} l^{-1}\right), 10 \mu \mathrm{l}\left[1^{-14} \mathrm{C}\right]$ acetylcoenzyme A $\left[0.2 \mathrm{mM}\right.$, specific activity $\left.5 \mathrm{Ci} \mathrm{mol}^{-1}\left(185 \mathrm{GBq} \mathrm{mol}^{-1}\right)\right]$ and $20 \mu \mathrm{l}$ cell extract. After $30 \mathrm{~min}$ incubation at $37^{\circ} \mathrm{C}, 35 \mu \mathrm{l}$ samples were pipetted on to $20 \times 20 \mathrm{~mm}$ squares of Whatman P81 cellulose phosphate paper. The papers were washed three times in water, dried and the radioactivity measured by liquid scintillation spectrometry as described previously (Shannon et al., 1978). In some experiments the concentration of aminoglycoside was increased to $200 \mu \mathrm{g} \mathrm{ml}^{-1}$ and that of acetyl-coenzyme $A$ to $1 \mathrm{mM}$. The same procedure was used for 
Table 2. Plasmids used in the study

\begin{tabular}{|c|c|c|c|}
\hline $\begin{array}{c}\text { Plasmid } \\
\text { no. }\end{array}$ & Characters* & $\begin{array}{l}\text { Inc } \\
\text { group }\end{array}$ & Reference or source \\
\hline$F^{\prime} 13$ & $\operatorname{argF}^{+} \operatorname{lac}^{+}$tsx $x^{\mathrm{S}}$ purE $E^{+}$ & FI & Hirota \& Sneath (1961) \\
\hline RGN238 & & FI & Matthew \& Hedges (1976) \\
\hline R1411 & Ap Sm Cm Su Km & FI & Chau et al. (1982) \\
\hline pGC400 & Ap Sm Cm Su Km Tp & FIV & G. Cornelis \\
\hline JR220 & Ap Tc AAC(3)IV production & & Davies \& O'Connor (1978) \\
\hline JR221 & Ap Tc AAC(3)IV production & & Davies \& O'Connor (1978) \\
\hline JR228 & AAC(3)IV production & & Davies \& O'Connor (1978) \\
\hline R1 & Ap Sm Cm Km Su & FII & Jacob et al. (1977) \\
\hline R5 & AAC $\left(6^{\prime}\right)$ production & & Benveniste \& Davies (1971) \\
\hline R27 & Tc & H1 & Jacob et al. (1977) \\
\hline $\mathbf{R} 726$ & $\mathrm{Sm} \mathrm{Tc} \mathrm{Cm} \mathrm{Su}$ & H1 & Jacob et al. (1977) \\
\hline R477-1 & $\mathrm{Sm} \mathrm{Tc} \mathrm{Su}$ & $\mathrm{H} 2$ & Jacob et al. (1977) \\
\hline R478 & Tc $\mathrm{Cm} \mathrm{Km}$ & $\mathrm{H} 2$ & Jacob et al. (1977) \\
\hline pUZ2 & Ap Tc AAC(3) production & $\mathbf{M}$ & Gomez-Lus et al. (1980) \\
\hline pTH1 & Ap Sm Tc Cm Su Tp AAC(3)I production & $\mathbf{M}$ & Datta et al. (1979) \\
\hline RIP135 & Sm Tc Su AAC(3)I production & $\mathbf{M}$ & Jacob et al. (1977) \\
\hline R446b & Sm Tc & $\mathbf{M}$ & Jacob et al. (1977) \\
\hline R64 & $\mathrm{Sm} \mathrm{Tc}$ & $\mathrm{Il}$ & Jacob et al. (1977) \\
\hline R483 & Sm Tp & I1 & Jacob et al. (1977) \\
\hline RAI & $\mathrm{Tc} \mathrm{Su}$ & $\mathrm{C}$ & Jacob et al. (1977) \\
\hline R6K & Ap Sm & $\mathbf{X}$ & Jacob et al. (1977) \\
\hline $\mathbf{R} 702$ & $\mathrm{Sm} \mathrm{Tc} \mathrm{Km} \mathrm{Su}$ & $\mathbf{P}$ & Jacob et al. (1977) \\
\hline pHH1307 & Ap Su Tp AAC (3) production & W & Nugent \& Datta (1980) \\
\hline pCERr35 & AAC (3) production & & Rubens et al. (1981) \\
\hline R1547 & Ap Su Tc Cm Km Su AAC(3)II production & & K. E. Price \\
\hline R1549 & Ap AAC(3)III production & & K. E. Price \\
\hline
\end{tabular}

- Abbreviations: Ap, ampicillin resistance; Sm, streptomycin resistance; Tc, tetracycline resistance; $\mathrm{Cm}$, chloramphenicol resistance; $\mathrm{Km}$, kanamycin resistance; $\mathrm{Su}$, sulphonamide resistance; $\mathrm{Tp}$, trimethoprim resistance.

adenylylation, with $200 \mu \mathrm{g}$ aminoglycoside $\mathrm{ml}^{-1}$ and with the acetyl-coenzyme A substituted by $\left[8^{-14} \mathrm{C}\right] \mathrm{adenosine}$ $5^{\prime}$-triphosphate [1 mM, specific activity $\left.5 \mathrm{Ci} \mathrm{mol}^{-1}\left(185 \mathrm{GBq} \mathrm{mol}^{-1}\right)\right]$.

The stability of apramycin acetates to alkali was tested by incubation with $\mathrm{NaOH}(1 \mathrm{M})$ at $0{ }^{\circ} \mathrm{C}$ for $10 \mathrm{~min}$ or at $60^{\circ} \mathrm{C}$ for $1 \mathrm{~h}$, followed by neutralization with $\mathrm{HCl}$ before pipetting on to cellulose phosphate paper: controls were incubated with sodium chloride $(0.67 \mathrm{M})$ at $60^{\circ} \mathrm{C}$ for $1 \mathrm{~h}$. Chloramphenicol acetylated by the enzyme from a clinical isolate of Klebsiella was used as a known $O$-acetate: it was separated from unchanged $\left[{ }^{14} \mathrm{C}\right]$ acetylcoenzyme A by partition into toluene.

In order to test the ability of modifying enzymes to acetylate various neomycin acetates the following procedure was adopted. The initial reaction mixture consisted of $10 \mu \mathrm{l}$ neomycin $\left(200 \mu \mathrm{g} \mathrm{ml}^{-1}\right), 10 \mu \mathrm{l}$ non-radioactive acetylcoenzyme A (4 mM) and $70 \mu \mathrm{AAC}(3) \mathrm{IV}, \mathrm{AAC}\left(2^{\prime}\right)$ or AAC $\left(6^{\prime}\right)$. After $1 \mathrm{~h}$ at $37^{\circ} \mathrm{C}$, the mixture was heated to $90^{\circ} \mathrm{C}$ to inactivate the enzyme. The product was tested for its ability to serve as substrate for a range of acetyltransferases by the cellulose phosphate paper binding method, as described above, but with the concentration of $\left[{ }^{14} \mathrm{C}\right]$ acetyl-coenzyme $\mathrm{A}$ increased to $0.5 \mathrm{mM}$.

\section{RESULTS}

\section{Strains that did not modify aminoglycosides}

One class of apramycin-resistant isolates, consisting of three isolates represented by P78.351, was resistant to all the aminoglycosides tested, including amikacin (Table 3 ). In this it differed both from the other apramycin-resistant isolates from animals and from strains of $E$. coli $\mathrm{K} 12$ carrying plasmids that specify the various AAC enzymes. In contrast the aminoglycoside resistance pattern of $\mathrm{P} 78.351$ resembled that of the nek mutant and also that of TH42662, an aminoglycoside-resistant clinical isolate from St Thomas' Hospital that does not acetylate or adenylylate gentamicin.

Attempts to transfer the aminoglycoside resistance of P78.351 to E. coli $\mathrm{K} 12$ failed. No acetylation or adenylylation of apramycin or gentamicin by extracts of P78.351 was detected. 
Table 3. Susceptibility to aminoglycosides of apramycin-resistant organisms and organisms with known mechanisms of aminoglycoside resistance

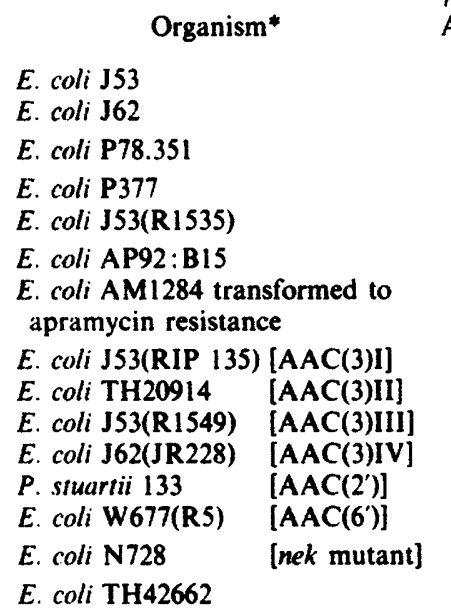

\begin{tabular}{rrrrrrr}
\multicolumn{6}{c}{ MIC values $\left(\mu \mathrm{g} \mathrm{ml}^{-1}\right)$} \\
Apramycin & Tobramycin & Gentamicin Amikacin & Kanamycin & Neomycin \\
2 & $0 \cdot 5$ & $0 \cdot 25$ & 1 & 2 & 1 \\
4 & 1 & $0 \cdot 5$ & 2 & 4 & 4 \\
128 & 32 & 16 & 128 & 128 & 32 \\
$>1024$ & 256 & 128 & 4 & $>1024$ & 1024 \\
$>1024$ & 256 & 128 & 2 & $>1024$ & 1024 \\
128 & 1 & 2 & 4 & $>1024$ & 1024 \\
128 & 1 & 1 & 2 & 8 & 64 \\
& & & & & \\
4 & 2 & 64 & 4 & 4 & 4 \\
4 & 32 & $>128$ & 4 & 16 & 4 \\
4 & $>512$ & 256 & 2 & $>1024$ & 64 \\
$>1024$ & 32 & 256 & 1 & 8 & 8 \\
16 & 512 & 512 & 8 & 8 & 128 \\
16 & 64 & 4 & 128 & $>1024$ & 16 \\
64 & 4 & 8 & 32 & 32 & 16 \\
1024 & 128 & 256 & 512 & 512 & 256
\end{tabular}

* Mechanisms of resistance of standard strains are shown in square brackets.

\section{P377, a strain that produced $A A C(3) I V$}

The second class of apramycin-resistant isolates, consisting of a single isolate P377, was resistant to all the aminoglycosides tested except amikacin (Table 3 ). The aminoglycoside resistance of this strain, together with the resistance it possesses to chloramphenicol, sulphonamide and trimethoprim, was transferable to $E$. coli $\mathrm{K} 12$ and was carried on a plasmid, designated R1535, of about $70 \mathrm{MDal}$. The plasmid was incompatible with R64 and hence assignable to incompatibility group I1. The pili determined by R1535 were characteristic of group Il (D. E. Bradley, personal communication).

Although R1535 was efficiently eliminated by entry of R64, one transconjugant was noted, among $\mathbf{4 0}$ tested, that had lost resistance to chloramphenicol and trimethoprim and suffered a decrease in its level of resistance to kanamycin (MIC decreased from $>1024$ to $32 \mu \mathrm{g} \mathrm{ml}^{-1}$ ), but retained resistance to sulphonamide and the aminoglycosides gentamicin, tobramycin and apramycin. Plasmid R64 was freely transferred from this strain with an efficiency of about $10^{-3}$ per donor $\mathrm{h}^{-1}$ and with no alteration in molecular weight or resistance characteristics. The resistances derived from $\mathrm{R} 1535$ were transferred at about $10^{-9}$ per donor $\mathrm{h}^{-1}$. Transconjugants that received the aminoglycoside resistance derived from $R 1535$ also received sulphonamide resistance (10 out of 10 tested), and both resistances subsequently cotransferred with the resistances specified by $\mathrm{R} 64$ as part of a single II group plasmid (subject to elimination by R483) that was slightly larger than R64.

Apramycin resistance, together with resistance to gentamicin and tobramycin, was transduced by phage Plkc from this derivative of R64 into the plasmid-free E. coli strain X1952. By conjugation of the transductant with $\mathrm{HfrH}$ the genetic determinant of apramycin resistance was found to have inserted into the bacterial chromosome near the trp operon, since over $70 \%$ of $\operatorname{trp}^{+}$recombinants were susceptible to apramycin.

P377 did not adenylylate gentamicin. However, it produced an enzyme that acetylated all the compounds tested except amikacin and so was indistinguishable from AAC(3)IV (Table 4).

\section{$A P 92: B 15$, a strain that produced a nen' acetyltransferase}

The single isolate, AP92:B15, in the third class of apramycin resistance was resistant only to apramycin, neomycin, kanamycin and streptomycin of the aminoglycosides tested (Table 3 ) and also to sulphonamides. However, only the resistance to neomycin and kanamycin was readily 
transferable to $E$. coli K12. This occurred with an efficiency of about $10^{-3}$ per donor $\mathrm{h}^{-1}$ on a plasmid of group I1 designated R1539. Resistance to sulphonamide and streptomycin was frequently transferred along with R1539 and was presumed to be determined by a non-self-transmissible plasmid mobilized by R1539. Although it was not tested, the resistance to neomycin and kanamycin determined by R1539 is assumed to be due to aminoglycoside $3^{\prime}-O$ phosphotransferase.

Apramycin resistance was transferred at very low frequency to $E$. coli J62-1 : after overnight conjugation on filter paper an apparent rate of transfer of $10^{-9}$ to $10^{-10}$ was observed. Almost all the apramycin-resistant transconjugants were also resistant to kanamycin, that is possessed plasmid R1539. The two, of more than 30 tested, that were kanamycin-susceptible carried cryptic plasmids that seemed to be derivatives of R1539. The determinant of resistance to apramycin appeared to be more closely associated with the trp locus than with any other of the markers tested, since in three separate experiments a proportion of the recombinants $(3$ of 8,5 of 10 and 6 of 15) was trp $^{+}$whereas all had the other nutritional markers (pro, his, lac) of the J62-1 parent.

None of the transconjugants contained any DNA supercoil other than R1539 (approximately $60 \mathrm{MDal}$ ) or the slightly smaller cryptic derivative. Elimination of R 1539 by entry of R64 did not lead to loss of apramycin resistance and transfer of R1539 did not involve transfer of apramycin resistance. One recombinant resistant to both apramycin and kanamycin and having all the nutritional markers of $\mathrm{J} 62-1$ was designated $\mathrm{J} 62-1 \mathrm{Apr}^{\mathrm{R}}(\mathrm{R} 1539)$. Conjugal transfer of apramycin resistance from $\mathrm{J} 62-1 \mathrm{Apr}^{\mathrm{R}}(\mathrm{R} 1539)$ to other strains of $E$. coli $\mathrm{K} 12$ occurred with a frequency of $10^{-9}$ per donor $\mathrm{h}^{-1}$ or less and was always accompanied by transfer of R1539. Since other plasmids of incompatibility group II have been reported to mediate transfer of chromosomal genes (Datta \& Barth, 1976) it was concluded that apramycin resistance was determined by a chromosomal gene mobilized by R1539.

In attempts to map the site of the apramycin resistance determinant in $\mathrm{J} 62-1 \mathrm{Apr}^{\mathrm{R}}(\mathrm{R} 1539)$ it was found that Hfrs H, B9, KL99, KL208 and K196 transferred nutritional markers into J62-1 $\operatorname{Apr}^{\mathrm{R}}(\mathrm{R} 1539)$ with kinetics similar to those when J62-1 was the recipient. Thus the segment derived from AP92:B15 did not greatly influence the recombination distribution. The determinant was located at about $20 \mathrm{~min}$ on the E. coli K12 map (Bachmann \& Low, 1980) by selecting for nutritional markers and scoring for loss of apramycin resistance.

The presence of $\mathrm{R} 1539$ prevented growth of phage $\mathrm{P} 1$ and $\mathrm{J} 62-1 \mathrm{Apr}^{\mathrm{R}}(\mathrm{R} 1539)$ so transduction of apramycin resistance was impossible. However, transfer of the apramycin resistance determinant into a plasmid-free strain was accomplished by introduction of $F^{\prime} 13$ into J62-1 $\mathrm{Apr}^{\mathrm{R}}(\mathrm{R} 1539)$ and conjugation of this strain with JF568-2. Recombinants resistant to both rifampicin and apramycin were selected and from amongst these kanamycin-sensitive, lactosenon-fermenting clones were found. One of these, designated JF568-2 Apr ${ }^{\mathrm{R}}$, had all the auxotrophic markers of JF568-2 but was resistant only to apramycin and neomycin and contained no plasmid DNA.

Phage P1 was grown on JF568-2 $\mathrm{Apr}^{\mathrm{R}}$ and the lysate used to map the resistance determinant by transduction to KL188 and KL188-4. Selection for apramycin resistance gave $65 \%$ cotransduction of $p y r D^{+}$whereas selection for $p y r D^{+}$gave $36 \%$ apramycin-resistant progeny. With the $o m p A$ recipient $\mathrm{K} 1188-4$, it was found that the $o m p A^{+}$gene was cotransduced to $80 \%$ of apramycin-resistant transductants. Three-point mapping showed that the ompA gene lay between pyrD and the determinant of apramycin resistance.

There was no evidence for transposition since attempts to mobilize apramycin resistance by a range of plasmids including $\mathrm{R} 1, \mathrm{R} 64, \mathrm{R} 483, \mathrm{R} 446 \mathrm{~b}, \mathrm{RA} 1, \mathrm{R} 6 \mathrm{~K}$ and $\mathrm{R} 702$ produced either no recombinants or exclusively chromosomal recombinants. Chromosomal transformation allowed the transfer of the apramycin resistance of AP92:B15 into AM1284 with an efficiency of about $10^{-9}$ per recipient cell. This was significantly above the rate of spontaneous mutation to apramycin resistance, about $10^{-10}$, and, whereas all five mutants tested were resistant to a wide range of aminoglycosides, the transformants were resistant to apramycin and neomycin alone. One transformant was allowed to conjugate with various $\mathrm{Hfrs}$ and its resistance determinant was found to map at about $20 \mathrm{~min}$. 


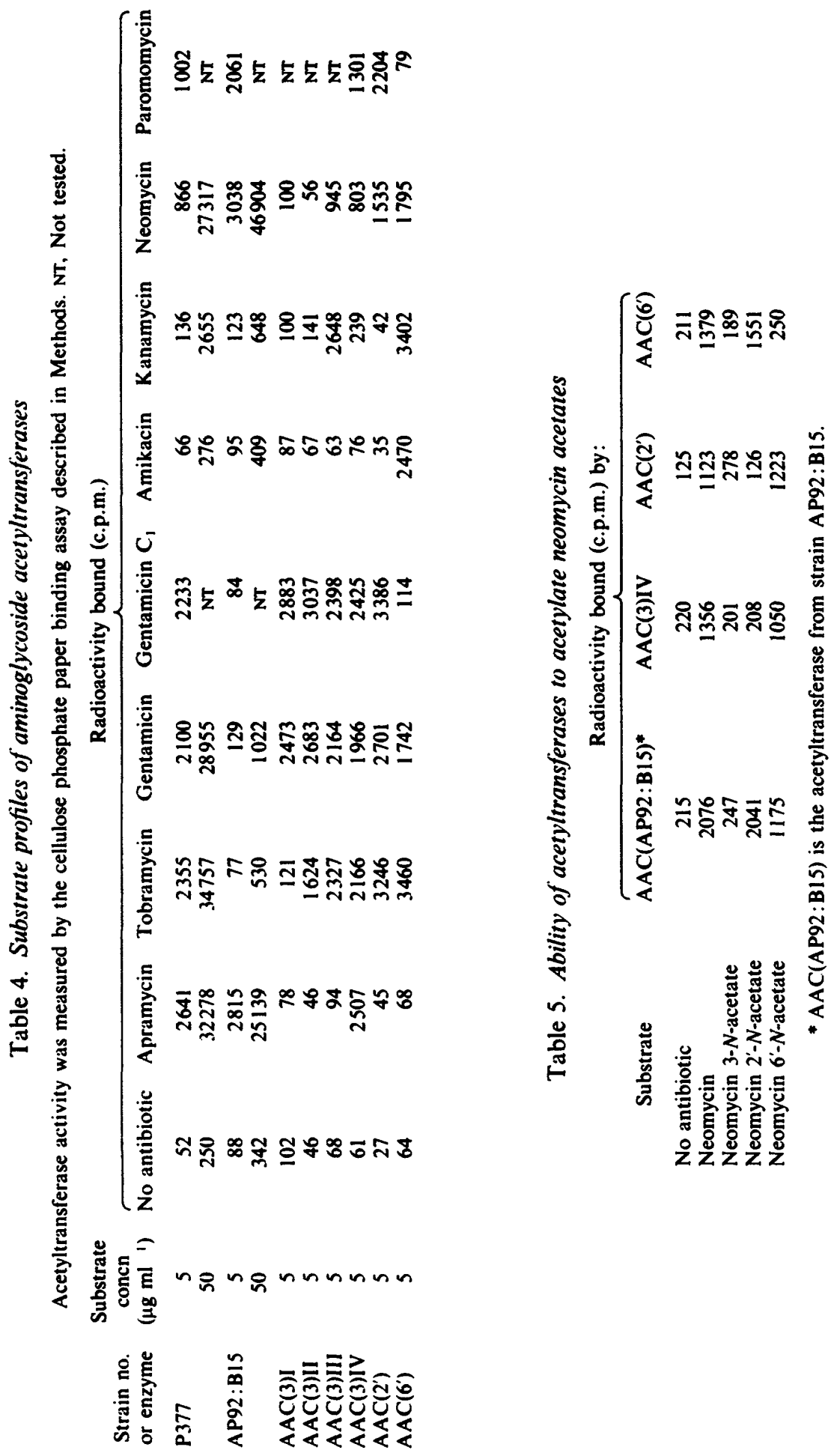


The extract from AP92:B15 did not adenylylate gentamicin but an enzyme was detected that acetylated neomycin, paromomycin and apramycin, but not other aminoglycosides, at the low substrate concentration usually used (Table 4). However, some other aminoglycosides were acetylated, albeit poorly, at a 10-fold higher substrate concentration. Strain AM1248 transformed to apramycin resistance produced an acetyltransferase that was indistinguishable from that of AP92:B15.

The ability of the enzyme from AP92:B15 and of standard amiñoglycoside-modifying enzymes to acetylate various neomycin acetates, prepared by incubation of neomycin with known acetyltransferases as described in Methods, is shown in Table 5. The enzyme from AP92: B15 was able to acetylate neomycin $2^{\prime}$ - and $6^{\prime}-N$-acetates but not neomycin $3-N$-acetate. Other enzymes differed in their ability to acetylate neomycin acetates (Table 5).

The apramycin acetates produced by the enzymes from AP92:B15 and P377 were stable to incubation at $60^{\circ} \mathrm{C}$ in the presence of $\mathrm{NaOH}$, whereas chloramphenicol acetate was almost completely destroyed in $10 \mathrm{~min}$, even at $0{ }^{\circ} \mathrm{C}$.

\section{Incompatibility testing of previously described apramycin resistance plasmids}

Incompatibility groups were determined for the plasmids conferring resistance to apramycin described by Davies \& O'Connor (1978). JR228, which confers resistance only to aminoglycosides, was incompatible with plasmids R27 and R726 (of group H1) and R477-1 and R478 (of group H2). JR220 and JR221, which confer resistance to ampicillin and tetracycline in addition to aminoglycosides, were incompatible with RGN238 and R1411 (of group FI) and pGC400 (of group FIV).

\section{Selection of apramycin-resistant derivatives of strains that produce $A A C(3)$ enzymes}

We had no success in attempts to obtain apramycin-resistant derivatives, able to grow in the presence of $25 \mu \mathrm{g} \mathrm{ml}^{-1}$, from large populations ( $>10^{11}$ cells) of strains of J53 carrying plasmids pUZ2, pTH1, pHH1307, RIP135, R1547 and R1549, all of which specify aminoglycoside acetyltransferases.

\section{DISCUSSION}

The acetyltransferase produced by strain P377 closely resembles that described by Davies \& O'Connor (1978) and designated AAC(3)IV. The plasmid specifying the enzyme in P377 belongs to incompatibility group I1, whereas the plasmids reported by Davies \& O'Connor (1978) belong to the F and H complexes. That plasmid JR220 was incompatible with reference plasmids of both groups FI and FIV is not too surprising since the compatibility relationships between plasmids assigned to group FI are complex and correlated with the numerous replication origin specificities demonstrated in the group (Bergquist et al., 1982): it may be that group FIV should be regarded merely as one section of an FI complex.

The lack of correlation of AAC(3)IV production with a particular plasmid group suggests transposability (Hedges \& Jacob, 1974; Hedges et al., 1974). We have shown this for the aminoglycoside and sulphonamide resistance from P377, which can enter the E. coli chromosome and also insert into plasmid R64 to produce the slightly larger derivative that has acquired the genes for aminoglycoside and sulphonamide resistance. We designate this transposon $\operatorname{Tn} 800$.

It has previously been shown that determinants for AAC(3) enzymes are transposable (Nugent \& Datta, 1980; Rubens et al., 1981) and there are indications that the genes for AAC(3)I and AAC(3)III are related (Rubens et al., 1981). Thus it is interesting to ask whether AAC(3)III and AAC(3)IV are related. A simple explanation would be an alteration in the gene for AAC(3)III that reduces the specificity of the enzyme so that apramycin can be acetylated. However, we have failed to detect mutation to apramycin resistance by this mechanism in strains carrying genes for AAC(3)I, AAC(3)II or AAC(3)III.

The acetyltransferase from AP92:B15 is less easy to identify than that from P377. The acetylation of paromomycin, which differs from neomycin in having a hydroxy rather than an amino group attached to the carbon atom at the $6^{\prime}$ position, indicates that it is not an $\mathrm{AAC}\left(6^{\prime}\right)$. 
There is nothing in its substrate profile to distinguish clearly between $\mathrm{AAC}(3)$ and $\mathrm{AAC}\left(2^{\prime}\right)$. The ability of the enzyme to acetylate neomycin $2^{\prime}-$ and $6^{\prime}-N$-acetates suggests that it is not an $\operatorname{AAC}\left(2^{\prime}\right)$ or an $\mathrm{AAC}\left(6^{\circ}\right)$. However, the inability to acetylate neomycin $3-\mathrm{N}$-acetate does not indicate that it is an AAC(3). The stability of the product of its acetylation of apramycin to sodium hydroxide suggests that the enzyme may be an $\mathrm{N}$-acetyltransferase, not an $\mathrm{O}$-acetyltransferase (Dowding, 1979): however, in the absence of known aminoglycoside $O$-acetates for comparison, the evidence is not conclusive. Thus while we have been unable to locate the site of acetylation of aminoglycosides by this enzyme, it is clearly distinct from aminoglycoside acetyltransferases previously described. Identification of its site of action will require determination of the structures of its products which, unfortunately, is beyond our capabilities. This enzyme could be more common than we think since apramycin susceptibility is seldom tested and neomycin resistance is likely to be ascribed to production of aminoglycoside $3^{\prime}-O$-phosphotransferase - a common enzyme.

The genetic determinant of this enzyme is interesting in that it has a unique chromosomal location, although it is hard to understand how such a gene could evolve in situ. It is more plausible for the determinant to have been introduced as a transposon but subsequently to have lost transposability. Such defective transposons have been reported (Cornelis et al., 1981; Fayet et al., 1982; Link \& Reiner, 1982). Loss of transposability may be an advantage to a replicon since the selectively advantageous character cannot be acquired by a competitor. The asymmetrical transduction results also suggest that the apramycin resistance determinant might be carried on a DNA sequence for which no homologue exists in the $E$. coli $\mathrm{K} 12$ chromosome.

In principle, chromosomal transformation provides a most valuable technique for the analysis of genetic variation between strains of $E$. coli. The ability to transfer the whole range of enterobacterial plasmids into a common genetic (chromosomal) background has been most valuable in our understanding of plasmid organization and diversity (for example, Datta, 1974), but at present no similar technique is available to handle chromosomal diversity. The main problem with transformation is the very low efficiency of the process. This means that gene transfer may be undetected against the mutational background. The apramycin resistance of AP92:B15 provides an excellent test case since apramycin-resistant mutants are very rare and phenotypically distinguishable from transformants. Our evidence suggests that the transformed resistance determinant has integrated at a specific chromosomal site and behaves as a regular, mappable genetic marker. Thus, the transformation technique has proved usable and, if the efficiency of transformation could be improved, may be of value in surveying the range of genetic characters in $E$. coli.

We have not established the mechanism of resistance in strain P78.351. It is possible that it is a nek mutant since such mutants show similar broad-spectrum aminoglycoside resistance. On the other hand, it is at least equally likely that the strain owes its resistance to defective uptake of aminoglycosides, since this has been shown to be the most common mechanism of 'nonenzymatic' aminoglycoside resistance in clinical isolates of enterobacteria (Price et al., 1981).

Ose et al. (1976) found less than $1 \%$ of isolates of $E$. coli and salmonella, mostly from pigs and cattle, to be apramycin-resistant. However, the faeces of 8 out of 10 pigs contained small numbers $\left(<350\right.$ organisms $\mathrm{g}^{-1}$ ) of apramycin-resistant $E$. coli after, but not before, treatment with apramycin for $5 \mathrm{~d}$ (Bowen et al., 1976). The question remains as to whether apramycin resistance is rare in isolates from humans and, if so, why? Since production of AAC(3)IV confers resistance to gentamicin and tobramycin it is somewhat surprising that it has not been reported as a cause of resistance to these drugs in hospital isolates, although it could be that this is merely a failure to distinguish AAC3(IV) from AAC(3)III through omission of apramycin from the range of compounds tested. Since the gene specifying AAC(3)IV occurs on transmissible plasmids of incompatibility groups well represented in hospital isolates and is, at least in one case, transposable, it is unreasonable to suppose that it could not spread under hospital conditions. The only apparent reason for the failure to observe AAC(3)IV in hospital isolates is ecological separation of the bacteria of farm animals from the hospital flora. 
apramycin-resistant isolates of E. coli. Drs A. E. Jacob and W. P. M. Hoekstra provided help and advice on transformation procedures. Mrs K. Ellis (Hammersmith Hospital) helped with the determination of plasmid molecular weights. Drs W. P. M. Hoekstra, J. E. Davies (Biogen S. A., Geneva), B. Bachmann (Yale University), C. Rubens (Washington University) and D. G. Bobey (Bristol Laboratories, Syracuse, New York) provided bacterial strains and helpful advice. Aminoglycosides were provided by the following companies: apramycin and tobramycin by Lilly Research Laboratories, gentamicin by Nicholas Laboratories, amikacin and kanamycin by Bristol Laboratories, neomycin by Upjohn and paromomycin by Parke Davis.

\section{REFERENCES}

BACHMANN, B. J. \& Low, K. B. (1980). Linkage map of Escherichia coli K12, edition 6. Microbiological Reviews 44, 1-56.

Benveniste, R. \& Davies, J. (1971). Enzymatic acetylation of aminoglycoside antibiotics by Escherichia coli carrying an R factor. Biochemistry 10, 17871796.

Bergmans, H. E. N., van Die, I. M. \& Hoekstra, W. P. M. (1981). Transformation in Escherichia coli: stages in the process. Journal of Bacteriology 146, 564-570.

Bergquist, P. L., Lane, H. E. D., Malcolm, L. \& DownARD, R. A. (1982). Molecular homology and incompatibility in the IncFI plasmid group. Journal of General Microbiology 128, 223-238.

Bowen, R. E., Davies, J., Walton, J. R. \& Bennett, T. H. (1976). Apramycin, a new aminocyclitol aminoglycoside antibiotic: microbiological safety. In Proceedings of the Fourth International Pig Veterinary Society Congress. p. B3, Ames, Iowa.

BrodA, P. (1967). The formation of $\mathrm{Hfr}$ strains in Escherichia coli K12. Genetical Research 9, 35-47.

Brown, M. E. \& APIRION, D. (1974). Mapping a cluster of ribosomal genes in Escherichia coli. Molecular and General Genetics 133, 317-327.

Chau, P. Y., Ling, J., Threlfall, E. J. \& IM, S. W. K. (1982). Genetic instability of $R$ plasmids in relation to the shift of drug resistance patterns in Salmonella johannesburg. Journal of General Microbiology 128, 239-245.

Clowes, R. C. \& Hayes, W. (1968). Experiments in Microbial Genetics. Oxford: Blackwell Scientific Publications.

Coetzee, J. N., Datta, N. \& Hedges, R. W. (1972). R factors from Proteus rettgeri. Journal of General Microbiology 72, 543-552.

Cornelis, G., Sommer, H. \& Saedler, H. (1981). Transposon Tn951 ( Tnlac) is defective and related to Tn3. Molecular and General Genetics 184, 241-248.

DAtTA, N. (1974). Epidemiology and classification of plasmids. In Microbiology-1974, pp. 9-15. Edited by D. Schlessinger. Washington, DC: American Society for Microbiology.

DATTA, N. \& BARTH, P. T. (1976). Hfr formation by I pilus-determining plasmids in Escherichia coli K12. Journal of Bacteriology 125, 811-817.

Datta, N., Hedges, R. W., Shaw, E. J., Sykes, R. B. \& Richmond, M. H. (1971). Properties of an R factor from Pseudomonas aeruginosa. Journal of Bacteriology 108, 1244-1249.

Datta, N., Hughes, V. M., Nugent, M. E. \& Richards, H. (1979). Plasmids and transposons, their stability and mutability in bacteria isolated during an outbreak of hospital infection. Plasmid 2 , 182-196.
DAvies, J. \& O'CoNNOR, S. (1978). Enzymatic modification of aminoglycoside antibiotics: $3-\mathrm{N}$-acetyltransferase with broad specificity that determines resistance to the novel aminoglycoside apramycin. Antimicrobial Agents and Chemotherapy 14, 69-72.

DowDiNG, J. (1979). A novel aminoglycosidemodifying enzyme from a clinical isolate of Acinetobacter. Journal of General Microbiology 110, 239-241.

FAyet, O., Froment, Y. \& Piffaretti, J.-C. (1982). $\beta$ Lactamase-specifying plasmids isolated from Neisseria gonorrhoeae have retained an intact right part of a Tn3-like transposon. Journal of Bacteriology 149, 136-144.

Foulds, J. \& CHAI, T. J. (1978). New major outer membrane protein found in an Escherichia coli tolF mutant resistant to bacteriophage Tulb. Journal of Bacteriology 133, 1478-1483.

Gomez-Lus, R., Larrad, L., Rubio-Calvo, M. C., Navarro, M. \& Lasierra, M. P. (1980). AAC(3) and $\mathrm{AAC}\left(6^{\prime}\right)$ enzymes produced by $\mathrm{R}$ plasmids isolated in a general hospital. In Antibiotic Resistance, Transposition and Other Mechanisms, pp. 295303. Edited by S. Mitsuhashi, L. Roswal \& V. Krcmery. Prague \& Berlin: Avicenum \& Springer Verlag.

HAAS, M. J. \& Dowding, J. E. (1975). Aminoglycoside-modifying enzymes. Methods in Enzym$\operatorname{olog} y 43,611-628$.

HANCOCK, R. E. W. (1981). Aminoglycoside uptake and mode of action - with special reference to streptomycin and gentamicin. I. Antagonists and mutants. Journal of Antimicrobial Chemotherapy 8, 249-276.

HedGeS, R. W. \& JACOB, A. E. (1974). Transposition of ampicillin resistance from RP4 to other replicons. Molecular and General Genetics 132, 31-40.

Hedges, R. W. \& JACOBY, G. A. (1980). Compatibility and molecular properties of plasmid Rms149 in Pseudomonas aeruginosa and Escherichia coli K12. European Journal of Biochemistry 92, 491-498.

Hedges, R. W., Datta, N., Kontomichalou, P. \& SMITH, J. T. (1974). Molecular specificities of Rfactor-determined $\beta$-lactamases: correlation with plasmid compatibility. Journal of Bacteriology 117 , 56-62.

Henning, U., Sonntag, I. \& Hindennach, I. (1978). Mutants (ompA) affecting a major outer membrane protein of Escherichia coli K12. European Journal of Biochemistry 92, 491-498.

Hirota, Y. \& SNEATh, P. H. A. (1961). F' and F mediated transduction in Escherichia coli K12. Japanese Journal of Genetics 40, 377-385.

Hull, R., Klinger, J. D. \& MoOdy, E. E. M. (1976). Isolation and characterization of mutants of Escherichia coli $\mathrm{K} 12$ resistant to the new aminoglycoside 
antibiotic, amikacin. Journal of General Microbiology 94. 389-394.

Jacob. A. E., Shapiro, J. A., Yamamoto, L., Smith, D. I., Cohen, S. N. \& Berg, D. (1977). Plasmids studied in Escherichia coli and other enteric bacteria. In DNA Insertion Elements, Plasmids and Episomes, pp. 607-670. Edited by A. I. Bukhari, J. A. Shapiro \& S. L. Adhya. Long Island, New York: Cold Spring Harbor Laboratory.

LINK. C. D. \& REINER, A. M. (1982). Inverted repeats surround the ribitol-arabitol genes of $E$. coli. Nature, London 298, 94-96.

Low, K. B. (1973). Rapid mapping of conditional auxotrophic mutations in Escherichia coli $\mathrm{K} 12$. Journal of Bacteriology 113, 798-812.

MATthew, M. \& HeDGeS, R. W. (1976). Analytical isoelectric focusing of $\mathbf{R}$ factor-determined $\boldsymbol{\beta}$-lactamases : correlation with plasmid compatibility. Journal of Bacteriology 125, 713-718.

Nugent, M. E. \& DATTA, N. (1980). Transposable gentamicin resistance in IncW plasmids from Hammersmith Hospital. Journal of General Microbiology 121. 259-262.

Ose. E. E.. Ryden, R. \& Muenster, O. A. (1976). Apramycin, a new aminocyclitol antibiotic. 1. In itiro evaluation. In Proceedings of the Fourth International Pig Veterinary Society Congress. p. B2. Ames, lowa.

Ozanne, R., Benveniste, R., TIPPER, D. \& Davies, J. (1969). Aminoglycoside antibiotics: inactivation by phosphorylation in Escherichia coli carrying $\mathbf{R}$ factors. Journal of Bacteriology 100, 1144-1146.

Pearce, L. E. \& Meynell, E. (1968). Specific chromosomal affinity of a resistance factor. Journal of General Microbiology 50, 159-172.

Price, K. E., Kressel, P. A., Farchione, L. A., Siskin, S. B. \& Karpow, S. A. (1981). Epidemiological studies of aminoglycoside resistance in the U.S.A. Journal of Antimicrobial Chemotherapy 8 (suppl. A), 89-105.

Roth, J. R. (1970). Genetic techniques in studies of bacterial metabolism. Methods in Enzymology 17A, 3-35.

Rubens, C. E., Farrar, W. E., McGee, Z. A. \& SCHAFFNER, W. (1981). Evolution of a plasmid mediating resistance to multiple antimicrobial agents during a prolonged epidemic of nosocomial infections. Journal of Infectious Diseases 143, 170 181.

RYDEN, R. \& MOORE, B. J. (1977). The in-vitro activity of apramycin, a new aminocyclitol antibiotic. Journal of Antimicrobial Chemotherapy 3, 609-613.

Shannon, K. P., Phillips, I. \& King, B. A. (1978). Aminoglycoside resistance among Enterobacteriaceae and Acinetobacter species. Journal of Antimicrobial Chemotherapy 4, 131-142.

WALTON, J. R. (1978). Apramycin, a new aminocyclitol antibiotic. Journal of Antimicrobial Chemotherapy 4, 309-313. 